Journal

of Geography

Politics and Society

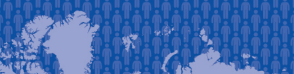

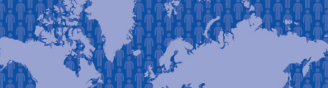

.

\section{.}

,

aces

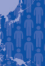

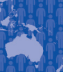

$7(3) / 2017$

\section{Journal of Geography, Politics and Society}

2017, 7(3), 82-87

DOI 10.4467/24512249JG.17.031.7187

\title{
BANK SECRECY IN POLAND AND THE EUROPEAN UNION - SELECTED ISSUES
}

\author{
Paulina Jaszczuk \\ Collegium luridicum, Faculty of Law, Canon Law and Administration, The John Paul II Catholic University of Lublin, Spokojna 1, 20-074 Lublin, Poland, \\ e-mail: jaszczuk.paulinaa@gmail.com
}

\section{Citation}

Jaszczuk P., 2017, Bank secrecy in Poland and the European Union - selected issues, Journal of Geography, Politics and Society, $7(3), 82-87$.

\begin{abstract}
Bank secrecy has a rich history and it may have originated as early as in the Code of Hammurabi, according to which particular regulations allowed for the protection of information of bankers' clients. Currently, the bank secrecy functions in most countries of the world. Its main aim is to protect our privacy in the financial circuit, mainly the data used for concluding transactions and contracts with the bank, so that our information was not given to the third parties. In the article, I will try to analyse the essence of the bank secrecy and And its functioning based on legal regulations, both in Poland and in the European Union on the example of selected states..
\end{abstract}

\section{Key words}

bank, banking law, bank secrecy, Poland.

\section{Introduction}

In today's world, each of us uses services that are offered by the banks, starting from ordinary, mundane services like daily payments with a card, right up to various kinds of credits or deposits. Activity of the banks is something common, and many of us cannot imagine an everyday life without non-cash transactions. Along with the functioning of the banks many issues appear, which require relevant legal regulations, including, inter alia, the bank secrecy. Its main aim is to protect our privacy in the financial circuit, to secure our data used for concluding transactions and contracts with the bank. In the article, I will try to analyse how the bank secrecy functions, Both in
Poland and in the European Union and its selected countries.

Bank secrecy in the present meaning formally appeared for the first time in Swiss banking law in 1934. However, the beginnings of its existence and functioning reaches back into antiquity. Although banking institutions did not operate at that time, nevertheless 4000 years ago the Code of Hammurabi contained provisions permitting the protection of confidential information of bankers' clients: the banker, also serving as a notary, could in the event of a dispute with the client disclose the entrusted documentation. Such a manner of exclusion, namely in the event of dispute with a client, allows to assume 
that, as a rule, disclosure of information was prohibited (Żygadło, 2011).

In addition, the beginnings of the bank secrecy can also be sought in Ancient Rome, where the principle of discretion was protected by actio iniuriarum, and in the customary law of barbaric tribes in lex visigothorum institution. On the other hand, reaching back to modern times, the Austrian consumer law from the 16th century should also be indicated, which was familiar with the principles of the financial secrecy. Financial privacy in the 19th century Germany even became a constitutional law. Currently, the bank secrecy exists nearly in every law system. Special attention should be paid to Switzerland, for the historical reasons and also due to the importance of this institution in the banking system. Switzerland is also an example of a country, which with the use of the biding principle of discretion in the client bank relations, has strengthened its economy in the world. On the other hand, the example of Great Britain depicts how the bank secrecy was shaped in the common law system, different from the positive law (Żygadło, 2011).

\section{The secret of banking in Poland}

In order to analyse legal regulations of the bank secrecy in Poland, it should be emphasized that the bank secrecy underwent an evolution in the course of the changes of the political system.

The basis of bank secrecy may be sought in the Constitution of the Republic of Poland', in Articles 47 and 51, which stipulate the right for protection of privacy and information on oneself, respectively. Information may be disclosed only based on provisions of statutory law, whereas the authorities can not gather, attain or share it.

The bank secrecy exclusions are classified according to interests indicated in the Article 31(3) of the Constitution of the Republic of Poland, for which limitation of right or freedom is acceptable, namely for the safety or public order, or for protection of environment, health and public morals, or freedom and rights of other persons. These restrictions cannot infringe the essence of rights and freedoms.

During the period of validity of the regulations of the Banking Law Act from 1989², there was an attempt to qualify the bank secrecy as type of state secret, treated as information important due to the

\footnotetext{
1 Konstytucja Rzeczypospolitej Polskiej z dnia 2 kwietnia 1997 r., Dz. U. z 1997 r. Nr 78, poz. 483 z późn. zm.

2 Ustawa z dnia 31 stycznia 1989 r. Prawo bankowe, Dz.U. $1989 \mathrm{nr} 4$ poz. 21.
}

interests of the state with regard to defence or safety, or as a type of professional secret, with which an employee becomes familiar during the performance of duties in a state-owned or a cooperative organizational unit. Analysing valid regulations of the Banking Law Act it should be emphasized that a concept was chosen, in accordance with which the bank secrecy is a special type of secrecy, the so-called professional confidentiality (Sikorski, 2011).

Bank secrecy main law in the Banking Act $^{3}$, Art. 104 of the law regulating the provision of individual as well as personal banking secrecy. The material scope of secrecy has been formulated according to the maximalism principle. It is worth emphasizing that bank secrecy also covers, apart from the contract itself, a business plan of the borrower, the content of contracts establishing credit claim provided as collateral, the financial condition of the borrower, the size and character of the borrower's assets and other additional information, which the bank came to possess, taking actions concerning this contractual relationship (Kaszubski, Tupaj-Cholewa, 2010). It suggests relatively wide range of validity of the bank secrecy.

Bank secrecy includes all information regarding bank's activity, and thus also the activities consisting in issuing payment cards, which have been obtained at the stage of negotiations of the contract terms, at the time of entering into the contract and during its implementation (and thus, for instance, in the course of executing a payment order made with a debit card). Owing to the use of the phrase "all information", such operation reinforces protection of such information, because the discussed provision results in an obligation to apply the broad interpretation in relation to the information as to which there is a doubt whether it should be classified within the scope of the bank secrecy. Hence, such information includes, inter alia, the number of the payment card, the data of the card holder, the PIN code and others (Kaszubski, Obzejta, 2012).

The scope and the principles of provision of information by the banks to some entities are regulated by separate Acts, apart from the Banking Law Act. This applies to:

- tax authorities (on this basis of the Tax Code);

- the General Inspector for the Financial Information, on this basis of the Act of 16 November 2000 on counteracting money laundering and terrorism financing ${ }^{4}$ (under this law, banks conducting

\footnotetext{
3 Ustawa z dnia 29 sierpnia 1997 r. - Prawo bankowe, Dz.U. 1997 nr 140 poz. 939 z późn. zm.

4 Ustawa z dnia 16 listopada 2000 r. o przeciwdziałaniu praniu pieniędzy oraz finansowaniu terroryzmu, t.j. Dz.U. z 2017 r. poz. 1049.
} 
a transaction whose value exceeds 15000 EUR are obliged to register such a transaction and inform it of this information by sending or providing transaction log data, among others transaction details, transaction date and amount);

- fiscal control authorities, on the basis of the Act of 28 September 1991 on fiscal control;

- confidant and its deputy, on the basis of the provisions of the Act on mortgage bonds and mortgage banks (Kawulski, 2013).

In addition, the ordinances lay down rules of processing the databases and other data containing information falling within the scope of bank secrecy by $\mathrm{CBA}^{5}$ or $\mathrm{ABW}^{67}$.

Data, which are collected by the banks already basically include not only our personal data, but also information regarding our financial situation, as well as our banking activities. All these data together, constitute the basis for determination of many aspects of our life. By analysing our transactions it can be easily determined what we like, what we do and where we are. Usually bearing in mind the freedom and ease of making non-cash transactions, We often forget that we are not completely anonymous when using this form of payment, and, in this case, we do not take into account issues concerning the safety and the confidentiality of such solutions (Mendis, Gałęziowska, 2015).

As it has been indicated in the decision of the Provincial Administrative Court in Warsaw, banks, in their very essence, are institutions of public trust ${ }^{8}$. For this reason, the banks are bound by an obligation of particular diligence in undertaking any actions, and in particular with regard to the obligation to keep bank secrecy and examination whether

5 pl. Centralne Biuro Antykorupcyjne - Central Anti-Corruption Buremu.

6 pl. Agencja Bezpieczeństwa Wewnętrznego - Internal Security Agency.

7 These are, for example: 1) Rozporządzenie Prezesa Rady Ministrów z dnia 6 maja 2013 r. w sprawie przetwarzania przez Centralne Biuro Antykorupcyjne informacji i danych stanowiących tajemnicę bankową oraz informacji dotyczących umów o rachunek papierów wartościowych, umów o rachunek pieniężny, umów ubezpieczenia lub innych umów dotyczących obrotu instrumentami finansowymi (Dz. U. z dnia 17 maja 2013 r.) Dz.U.2013.572 and (2) Rozporządzenie Prezesa Rady Ministrów z dnia 18 lipca 2016 r. w sprawie przetwarzanie przez Centralne Biuro Antykorupcyjne informacji i danych stanowiących tajemnicę bankową oraz informacji dotyczących umów o rachunek papierów wartościowych, umów o rachunek pieniężny, umów ubezpieczenia lub innych umów dotyczących obrotu instrumentami finansowymi (Dz. U. z dnia 19 lipca 2016 r.), Dz.U.2016.1057.

8 Wyrok Wojewódzkiego Sądu Administracyjnego w Warszawie z dnia 27 lutego 2004 r., sygn. II SA 291/03, LEX nr 569664. there are statutory premises allowing for waiving of this secrecy. Their primary role is to safeguard the interests of consumers, while maintaining adequate discretion.

As aptly reasoned by the Court of Appeal in Katowice, for the application for waiving of the bank secrecy it is unjustified to formulate non-statutory condition so that such information protected by the bank secrecy could not be obtained in any other way ${ }^{9}$. However, it should be pointed out that there is sufficient justification for the offense to be committed and that disclosure of the data subject to banking secrecy is sufficient to achieve the objectives of the criminal proceedings, including the efficiency and the process, which are intended to ensure that the offender is taken as soon as possible. The prosecutor may request the revocation of bank secrecy at any time and regardless of the state of the case, otherwise the purpose of the criminal proceedings could be terminated ${ }^{10}$. These regulations aiming at the speedy and effective conduct of both preparatory and judicial proceedings.

When indicating the material scope of the bank secrecy, it should be pointed out that it includes not only information about activities of the banks, but also data carriers (including documents) containing this information. It is important that we would otherwise have to deal with the situation, in which a carrier of information would be issued without waiving the bank secrecy, and provision of information included on this carrier would be subject to secrecy. All information entrusted to the bank by the client are covered by bank secrecy, including information necessary for preparation of banking activities, such as credit application and its justification, along with the enclosed documents. This information determines banking activities, constituting the basis for undertaking subsequent activities, therefore premises for including them in the bank secrecy are identical as premises for the secrecy of the activities themselves ${ }^{11}$.

It is worth noting about the new act on exchange of fiscal information with other states ${ }^{12}$, which sets principles and procedures of exchange of fiscal information with other states as well as obligations of financial institutions regarding exchange of that information. This might seem to interfere with the

\footnotetext{
9 Postanowienie Sądu Apelacyjnego w Katowicach z dnia 1 września 2010 roku, sygn.. II AKz 573/10, KZS 1/11 poz. 114.

10 Postanowienie z dnia 6 marca 2014 roku - II AKz 65/14 do III Kp 52/14 SO Kraków.

11 Postanowienie Sądu Apelacyjnego w Krakowie z dnia 30 marca 2009 r., sygn. II AKz 106/09, KZS 2009/5/48.

12 Ustawa z dnia 9 marca 2017 r. o wymianie informacji podatkowych z innymi państwami, Dz.U. z 2017 r. poz. 648.
} 
rules on bank secrecy. Pursuant to Article 6 of the said act the provisions limiting the access to the information legally protected, except for classified information, shall not be applicable to disclosure of information to the Minister of Finance and empowered institutions. The reason behind this regulation is to protect the financial institutions from claims on infringement of bank secrecy.

\section{Bank secrecy in the European Union}

As for the legislation of the European Union, the references to the bank secrecy are regulated in the essential legal act for the operation of the banks, namely the Second Council Directive of 15 December $1989^{13}$. In the Article 16, the bank secrecy was defined as professional secrecy, and at the same time the principles of the disclosure of secrecy was introduced. The provisions of the Council impose on the Member States of the European Union an obligation of introduction to their national legislation biding with bank secrecy of persons who have not only worked or are working for bank institutions, but also persons being auditors or experts, performing specific activities on behalf of the banks. It is also worth stressing that disclosure of information may occur only in the following circumstances:

- in the event of insolvency proceedings;

- towards banking supervisory authorities;

- as part of international cooperation concerning the exchange of information between competent state authorities (Pyzioł, 2001).

$\mathrm{KNF}^{14}$ in its letter of 28 December 2011 indicates that one of the objectives of the bank supervision is to ensure protection of confidential data covered by the bank secrecy. This protection bounds the banks and bank staff involved in the performance of banking operations. Access to the data covered by the bank secrecy is strictly regulated, and their disclosure can be done provided that the bank grants authorization for such activity. The guarantee of protection of bank secrecy is also applied in the EU law, in accordance with Directive 2006/48/EC relating to the taking up and pursuit of the business of credit institutions. It is worth emphasizing that waiving of the bank secrecy inconsistently with the provisions may result in tortious, contractual and criminal liability of

\footnotetext{
13 Druga Dyrektywa Rady z dnia 15 grudnia 1989 r. w sprawie koordynacji przepisów ustawowych, wykonawczych i administracyjnych odnoszących się do podejmowania i prowadzenia działalności przez instytucje kredytowe, zmieniająca dyrektywę 77/780/EWG.

14 pl. Komisja Nadzoru Finansowego - Polish Financial Supervision Commission
}

the bank, which prejudges a particularly significant role of the bank secrecy in the Act of 2002-Banking Law Act"15.

Turning to the detailed discussion of the bank secrecy in the selected other European countries, taking into account the Member States of the European Union, the aforementioned Directive 2006/48/ EC of the European Parliament and of the Council of 14.06.2006 on the taking up and pursuit of the business of credit institutions ${ }^{16}$ should also be discussed. In the context of the bank secrecy, Articles 42, 44-52 should first be emphasized, pursuant to which Member States are obliged to provide non-disclosure of professional confidentiality. In addition, Article 46 of the aforementioned directive states that the Member States may conclude cooperation agreement with competent authorities of third states allowing for the exchange of information only when disclosed information are covered by guarantees of protection of professional confidentiality. On the other hand, information originating from another Member State may only be disclosed on the basis of an explicit and necessary permission of competent authorities, which disclosed it.

The significance of the bank secrecy was also emphasized by the European Court of Human Rights in the case of M. N. and Others v. San Marino, emphasizing that the right for private life includes also the use of the bank secrecy. In the judgment it has been indicated that the information obtained from bank documents indisputably constitutes personal data concerning a natural person, regardless of the sensitivity of such information. In addition, such information may also relate to professional activities and, in principle, there is no justification for excluding professional or economic activities from the concept of „private life" [from art. 8 Convention]. It follows that the concept of ,private life' is applicable in the present case $^{17}$.

Going to discuss bank secrecy in selected other European Union countries, it should be pointed out that the English law shapes the bank secrecy based on the court rulings within the common law system, biding in this legal order.

In the UK the obligation to secure the bank secrecy is an implied element of agreement between the client ant the bank. However, it is not of an absolute but rather of a conditional nature. It may be defined

\footnotetext{
15 Pismo z dnia 28 grudnia 2011 r. Komisja Nadzoru Finansowego DNB/IV/7111/179/1/MSZ/11, M.Pr.Bank. 2012/9/4-6

16 Dyrektywa 2006/48/WE Parlamentu Europejskiego i Rady z dnia 14 czerwca 2006 r. w sprawie podejmowania i prowadzenia działalności przez instytucje kredytowe.

17 Wyrok Europejskiego Trybunału Praw Człowieka M.N. i inni v. San Marino z dnia 7 lipca 2015 r., sygn 28005/12.
} 
as "contractual", which allow to set the level of responsibility for potential infringements. In terms of subjective perimeter of the bank secrecy the case from the 20s of XX century was crucial. It is connected with the genesis of the bank secrecy in the UK - the Tournier cas $\mathrm{e}^{18}$. It was decided that the secrecy coveres not only the balance of the client's account, but also the transactions and all collaterals encumbering the given account. Additionally, all the data that the bank has attained during the time the account was opened is also included (Zawirska, 2010).

On the other hand, the examples of exemption from the bank secrecy were also included. These rules are still applicable. These are the following: disclosure of information upon the client's acceptance, disclosure under the provisions of law, public duty or the interest of the bank (Żygadło, 2011).

Prior to this verdict it was considered whether the confidentiality between the client and the bank is an outcome of a moral imperative. For instance in case Foster v. Bank of London from 1862 it was deliberated whether there is an obligation binding the bankers to keep secrecy with regard to balance of the client's accounts. The jury decided that there is such an obligation and the judge confirmed that any rule opposed to the jury's view had not existed (Żygadło, 2011).

It is worth pointing out that in English legislation, penal liability has not been provided in the case of violation of the obligation of confidentiality. On the other hand, the legal-civil liability is bound by the responsibility for the violation of the contract (Zawirska, 2010).

Another example is the aforementioned Switzerland, where banks and banking system became a symbol, and the history of the banking system stretches back to the 18th century, Although officially the banking secrecy of the regulated in 1934 in the banking law. It is caused, inter alia, by the adopted principle of inviolability of the bank secrecy, which consolidated the trust in Switzerland as the financial centre of Europe and the world. The bank secrecy is additionally stemming from the right to protect the privacy and wealth of the clients stipulated in the civil code.

A characteristic feature of Swiss Banks is the rigorous compliance with the bank secrecy. Both wilful and unintentional violation of the bank secrecy constitutes criminal offences punishable with 6 months in prison or a fine in the amount $50000 \mathrm{CHF}$, respectively. In addition, the disclosure of the bank secrecy takes place only in the cases strictly defined by the

18 Tournier v. National Provincial and Union Bank of England, 1924, Kings Bench Division 461. regulations, which also applies to the foreign prosecution bodies(Gostomski, 2007).

In France, Austria, Luxembourg and the Netherlands, likwise in Switzerland, infringement of the bank secrecy is punished however only if made deliberately. The bank secrecy is strongly protected also in Liechtenstein and Singapore.

\section{Conclusion}

Bearing in mind the issues indicated above, I think that preservation of the bank secrecy is an extremely important obligation, which the banks must face. In conclusion, it must be stated that in the face of continual changes, in Europe, and not coincide with the functioning of banking secrecy, banks as institutions of public trust should strive even more to ensure loyalty of clients, in the face of the willingness to protect personal data and the additional information, which the banks possess, due to the tasks performed by them. Certainly building trust is not the case when bank employees steal customer data and databases, all of which contribute to the fact that people sometimes simply fear to produce their identity card, even necessary to set up a bank account. It seems that looking at such situations is a good solution, to exacerbate the penalties in Polish penal law for such behavior and action as it is in the above described Switzerland.

\section{References}

Druga Dyrektywa Rady z dnia 15 grudnia 1989 r. w sprawie koordynacji przepisów ustawowych, wykonawczych i administracyjnych odnoszących się do podejmowania i prowadzenia działalności przez instytucje kredytowe, zmieniająca dyrektywę 77/780/EWG.

Dyrektywa 2006/48/WE Parlamentu Europejskiego i Rady z dnia 14 czerwca 2006 r. w sprawie podejmowania i prowadzenia działalności przez instytucje kredytowe.

Gostomski E., 2007, System bankowy w Szwajcarii, Acta Universistatis Lodziensis, Folia Oeconomica, 209, 93-101.

Kaszubski R., Obzejta Ł., 2012, Karty płatnicze w Polsce, LEX Wolters Kluwer businnes, Warszawa.

Kaszubski R., Tupaj-Cholewa A., 2010, Prawo bankowe, Wolters Kluwer business, Warszawa.

Kawulski A., 2013, Prawo bankowe - komentarz, LexisNexis, Warszawa.

Konstytucja Rzeczypospolitej Polskiej z dnia 2 kwietnia 1997 r., Dz. U. z 1997 r. Nr 78, poz. 483 z późn. zm.

Mendis A., Gałęziowska K., 2015, Ochrona tajemnicy bankowej w świecie „Big data”, Ochrona Danych Osobowych, 5, 12-15.

Pismo z dnia 28 grudnia 2011 r. Komisja Nadzoru Finansowego DNB/IV/7111/179/1/MSZ/11, M. Pr. Bank. 2012/9/4-6. 
Postanowienie Sądu Apelacyjnego w Katowicach z dnia 1 września 2010 roku, sygn.. II AKz 573/10, KZS 1/11 poz. 114

Postanowienie Sądu Apelacyjnego w Krakowie z dnia 30 marca 2009 r., sygn. II AKz 106/09, KZS 2009/5/48.

Postanowienie z dnia 6 marca 2014 roku - II AKz 65/14 do III Kp 52/14 SO Kraków.

Pyzioł W., 2001, Encyklopedia prawa bankowego, LexisNexis, Warszawa.

Rozporządzenie Prezesa Rady Ministrów z dnia 18 lipca 2016 r. w sprawie przetwarzanie przez Centralne Biuro Antykorupcyjne informacji i danych stanowiących tajemnicę bankową oraz informacji dotyczących umów o rachunek papierów wartościowych, umów o rachunek pieniężny, umów ubezpieczenia lub innych umów dotyczących obrotu instrumentami finansowymi (Dz. U. z dnia 19 lipca 2016 r.), Dz.U.2016.1057.

Rozporządzenie Prezesa Rady Ministrów z dnia 6 maja 2013 r. w sprawie przetwarzania przez Centralne Biuro Antykorupcyjne informacji $i$ danych stanowiących tajemnice bankowq oraz informacji dotyczących umów o rachunek papierów wartościowych, umów o rachunek pieniężny, umów ubezpieczenia lub innych umów dotyczących obrotu instrumentami finansowymi (Dz. U. z dnia 17 maja 2013 r.) Dz.U.2013.572

Sikorski G., 2011, Egzekucja z rachunków bankowych, Currenda, numer 159421, LEX.

Tournier v. National Provincial and Union Bank of England, 1924, Kings Bench Division 461.

Ustawa z dnia 16 listopada 2000 r.o przeciwdziałaniu praniu pieniędzy oraz finansowaniu terroryzmu, t.j. Dz.U. z 2017 r. poz. 1049.

Ustawa z dnia 29 sierpnia 1997 r. - Prawo bankowe, Dz.U. 1997 nr 140 poz. 939 z późn. zm.

Ustawa z dnia 31 stycznia 1989 r. Prawo bankowe, Dz.U. 1989 $\mathrm{nr} 4$ poz. 21.

Ustawa z dnia 9 marca 2017 r. o wymianie informacji podatkowych z innymi państwami, Dz.U. z 2017 r. poz. 648.

Wyrok Europejskiego Trybunału Praw Człowieka M.N. i inni v. San Marino z dnia 7 lipca 2015 r., sygn. 28005/12.

Wyrok Wojewódzkiego Sądu Administracyjnego w Warszawie z dnia 27 lutego 2004 r., sygn. II SA 291/03, LEX nr 569664.

Zawirska P., 2010, Tajemnica bankowa a prywatność - przykład Szwajcarii i Anglii, Studia Prawnicze, 3-4, 9-47.

Żygadło A., 2011, Wyłączenia tajemnicy bankowej a prawo do prywatności, LEX Wolters Kluwer businnes, Warszawa. 